ARCHAEOLOGY IN GREECE 2017-2018

\title{
A survey of Late Bronze Age funerary archaeology over the last 25 years in the central and southern Aegean
}

\author{
Yannis Galanakis | University of Cambridge | ig298@cam.ac.uk
}

This contribution offers a brief survey of funerary archaeology undertaken in the central and southern Aegean over the course of the last 25 years. Major construction projects and salvage and systematic excavations have brought to light some 1,700 new Late Bronze Age tombs (i.e. 27\% of the extant corpus). Despite these discoveries, however, very few tombs have received a final publication and few of these projects are context driven. New data are and will continue to be desirable - but it is the quality of the recording of these data, our research questions and the careful application of new methodologies, during and after excavation, that will open up new interpretative avenues and debates. With the number of secure archaeological contexts dwindling fast, not least because of the constant threat of looting, developing new approaches (for example understanding site formation and episodes of use) is crucial if we are to recover as much as possible and advance our knowledge of the multivalent roles played by burials within ancient societies.

Twenty years have passed since the publication of A Private Place: Death in Prehistoric Greece by William Cavanagh and Christopher Mee (1998) and Olivier Pelon's update (1998) on the state of research on tholos tombs. Even more time has lapsed since the last island-wide survey of Late Bronze Age (LBA) tombs on Crete by Wanda Löwe (1996). Therefore, it is timely to offer a brief update on the current state of research. After all, the Archaiologikon Deltion, Chronique des Fouilles and Archaeological Reports have all proved for generations of scholars a first port of call for new discoveries. Given the timing of publication, I would like to dedicate this short contribution to the aforementioned researchers who, with their syntheses, gave us all a starting point for further exploration, paving the way for the advancement of knowledge through discussion and debate.

Since the 1860s, the total number of LBA tombs known in the southern Aegean has risen to $c a .6,200$. In the last 25 years alone, more than 1,686 tombs ( $c a .27 \%$ of the extant corpus) have been discovered at 207 sites, some well-known, others totally new (for comparison, Cavanagh and Mee (1998) list 442 sites for all Prehistoric burials, excluding Crete). To compile this survey, I relied on the Archaiologikon Deltion (up to number 68, published in 2017, and volume 69, covering activity in 2013), Archaeology in Greece Online, conferences and their proceedings, specialized studies, as well as local and international news reports and the edited volume Anaskaphes (Vlazaki 2012). Table 3 and Table 4 summarize the tombs discovered in the last 25 years by type and by number of sites per region. The five maps that accompany this contribution help illustrate their distribution (arranged by type). Without final publications for most of the tombs, it is difficult at present to offer a refined listing based on dates of construction and use, though reference to some of the most important discoveries is made below.

The record of publication of funerary contexts has always been uneven in Aegean archaeology. For example, some tomb types, especially shaft graves, tholoi and chamber tombs, have consistently received more prominence in archaeological discourse than others. At the same time, while some tombs and cemeteries received a first publication before World War II (e.g. Knossos, Dendra, Mycenae, Prosymna and Ialysos, to name but a few notable sites), their excavation falls short of modern practices, which later hampers publication and limits interpretation.

Following broader developments in archaeology over the course of the last 25 years, it is noticeable how much effort now goes into integrating the different aspects of the burial rather than solely focusing on the objects discovered in the tombs, which for a long time formed the main preoccupation of excavators and scholars. Bioarchaeology, zooarchaeology, archaeobotany, micromorphology, section drawings, digital recording, archival integration and efforts to understand better episodes of use, tomb construction, 


\begin{tabular}{ll} 
Tomb type & Number \\
\hline Tholos and tholoid tombs & 89 (at 40 sites) \\
Chamber tombs & 809 (at 124 sites) \\
Built chamber tombs & 21 (at 13 sites) \\
Pit caves and double pits & 54 (at six sites) \\
Shaft graves & 8 (at three sites) \\
Pits, cists and other graves & 705 (at 54 sites) \\
Total & $\mathbf{1 , 6 8 6}$
\end{tabular}

Table 3. The numbers of tombs discovered in the last 25 years grouped by type.

\begin{tabular}{lc} 
Region & Sites \\
\hline Crete & 30 \\
Thessaly (incl. Olympos and Skyros) & 27 \\
Elis & 20 \\
Phthiotis and Phocis & 20 \\
Messenia & 18 \\
Argolid and Corinthia & 17 \\
Achaea & 15 \\
Attica and the Saronic gulf & 14 \\
Laconia and Kythera & 13 \\
Western Greece & 10 \\
Dodecanese & 7 \\
Western Turkey & 5 \\
Boeotia & 3 \\
Cyclades & 3 \\
Northeastern Aegean & 2 \\
Arcadia & 1 \\
Euboea & 1 \\
Total & $\mathbf{2 0 7}$
\end{tabular}

Table 4. The numbers of sites where tombs have been
discovered in the last 25 years grouped by region.

landscape associations as well as the rituals involved are now becoming integral to excavation planning. ${ }^{1}$ If we are to identify attitudes towards death, taking a holistic approach to the excavation of funeral contexts is imperative. There is certainly a great deal still to be done, not least as most contexts remain unpublished and the cost of excavating them carefully is considerable and often requires time. However, given that most of the tombs and their associated burials will continue to be excavated as part of rescue excavations - with limited or no specialists and specialized equipment at hand for assistance - it is vital for excavators to have the necessary training (e.g. in how and what to record, how to take samples and from what contexts, how best to proceed with the excavation of demanding digs, etc.). This way the collection of data will be improved significantly and any future study of the excavated material for publication will be immensely facilitated.

In short, it is not simply more data that we need (we already have plenty); rather, it is the quality of the data, our research questions and the application of careful methodologies in the course of excavation that will help us advance knowledge. It is indeed worth remarking that the last 20 years have witnessed important strides in the excavation of LBA tombs and their associated burials; while the 1980s and 1990s were characterized by advances on a theoretical level in Aegean archaeology, the 2000s and 2010s have been more methodologically focused. Although undoubtedly much still needs to be done, the record of publication is improving steadily, often generously supported by INSTAP. The same is true for the now more systematic preliminary reporting of tombs and the restudy of old material based on modern standards
Therefore the discovery of more horse burials near chamber tombs 2, 15 and 16 at Dendra constitutes an intriguing case study (ID2413, ID4421; Pappi and Isaakidou 2015). 
(e.g. at Pylos in Messenia by Sharon Stocker, Jack Davis and Joanne Murphy; at Kakovatos in Elis by Birgitta Eder and her team; at Argos in the Argolid by Anna Touchais and Nikos Papadimitriou and at Eleona Langada on Kos by Salvatore Vitale and his team, to mention but a few notable projects).

To my knowledge, more than 40 relevant PhDs have been written since the mid-1990s, some later published as monographs. Some have a regional or interregional focus (e.g. Löwe 1996 and Preston 2000 on Crete; Evangelou 2009 on central Crete; Psallida 2012 on eastern Crete; Salavoura 2015 on Arcadia; Boyd 2002 and Zavadil 2013 on southwestern Peloponnese; Nikolentzos 2009 on Elis; Sjöberg 2004 on the Argolid; Voutsaki 1993 on the Argolid, Thessaly and the Dodecanese; Georgiadis 2003 and Eerbeek 2014 on the Dodecanese), ${ }^{2}$ while others examine particular tomb types (e.g. Papadimitriou 2001 on built chamber tombs; Galanakis 2007 on tholos tombs; Lewartowski 2000 on 'simple graves'). Some other studies discuss whole cemeteries (e.g. Müller 1995; Kolonas 1998; Papadimitriou-Grammenou 2003; Alberti 2004; Vikatou 2009; Paschalidis 2014; Malapani 2015; Papadopoulou 2015; PapadopoulouChrysikopoulou 2015; Kaskantiri 2016) or focus on specific aspects of funerary archaeology in general (e.g. Effinger 1996 on jewellery; Fitzsimons 2006 on elite architecture at Mycenae; Gallou 2005 and Hristova 2010 on ritual; Giannopoulos 2008, Grigoropoulos 2011 and Steinmann 2012 on warrior burials; Kountouri 2002 on pottery; Leith 2013 on gender; Pomadère 2007 on children; Iezzi 2005, Nafplioti 2007 and Moutafi 2015 on LBA bioarchaeology).

There are also important final publications of old or more recent excavations: for example, to name but a few, Agia Sotira in the Nemea valley (Smith et al. 2017), Mochlos in eastern Crete (Soles et al. 2008; Smith 2010; Soles and Davaras 2011), Kalochoraphitis in south-central Crete (Karetsou and Girella 2015), Pylona on Rhodes (Karantzali 2001), Chalandritsa in Achaea (Aktypi 2017), Aigion in Achaea (Papadopoulos and Papadopoulou-Chrysikopoulou 2017), Brauron in Attica (Papadopoulos and KontorliPapadopoulou 2014), Merenda in Attica (Salavoura 2006), Lazarides on Aegina (Efstratiou and Polychronakou-Sgouritsa 2016) and Strephi in Elis (Nikolentzos 2016).

The publication of specialized edited volumes has helped to mesh together further the different strands of archaeological research. Recent volumes include Staging Death (Dakouri-Hild and Boyd 2017), Embodied Identities (Mina et al. 2016), Metaphysis (Alram-Stern et al. 2016), Mycenaeans up to Date (Schallin and Tournavitou 2015), New Directions in the Skeletal Biology of Greece (Schepartz et al. 2009) and the forthcoming proceedings of the 17th International Aegean conferences Mneme: Past and Memory in the Aegean Bronze Age and (Social) Place and Space in Early Mycenaean Greece that include several papers dealing with funerary matters. There are also a very large number of articles in journals and regionally focused conferences, to which in a short review like this it would be impossible to do justice. ${ }^{3}$ Depending on interests, readers are encouraged to search relevant titles via Nestor: https://classics.uc.edu/nestor/.

Despite the important technological developments which now assist research and expedite publication, traditional records remain equally important. For example, the surfacing of Panagiotis Stamatakis' diaries of the 1876-1877 excavation of the Shaft Graves at Mycenae now allows us for the first time to associate most of the discovered objects with particular burials: see the four 'Mycenae revisited' articles (Nafplioti 2009; Papazoglou-Manioudaki et al. 2009; 2010; Dickinson et al. 2012) and the article by Eleni Konstantinidi-Syvridi (2018) on Shaft Grave III (and Konstantinos Paschalidis recently presented his work on Shaft Grave IV in London in May 2018 at the Mycenaean seminar, in a paper titled 'Shaft Grave IV in Grave Circle A: new and unexpected light in a very old story'). All in all, the key word here is 'integration'

\footnotetext{
${ }^{2}$ For a synthesis of information on tombs and cemeteries in Attica, see also Privitera 2013.

3 Notable also are the advances in DNA and strontium analyses (on the latter, see, e.g., the work of Nafplioti 2011) and micromorphology (Karkanas et al. 2012). Two important recent articles include Murray 2018 on Perati and Jones et al. 2018 on radiocarbon dating of the multiple
}

levels of use of the Mycenaean tholos tomb of Petroto in Achaea. In general, we need more radiocarbon dates from funerary contexts and more extensive use of GIS (the most important work to date is the PhD by Kalliopi Efkleidou [2014]; for some other attempts, see Svenson 2013; Jazwa and Jazwa 2017; Sharma 2017). 


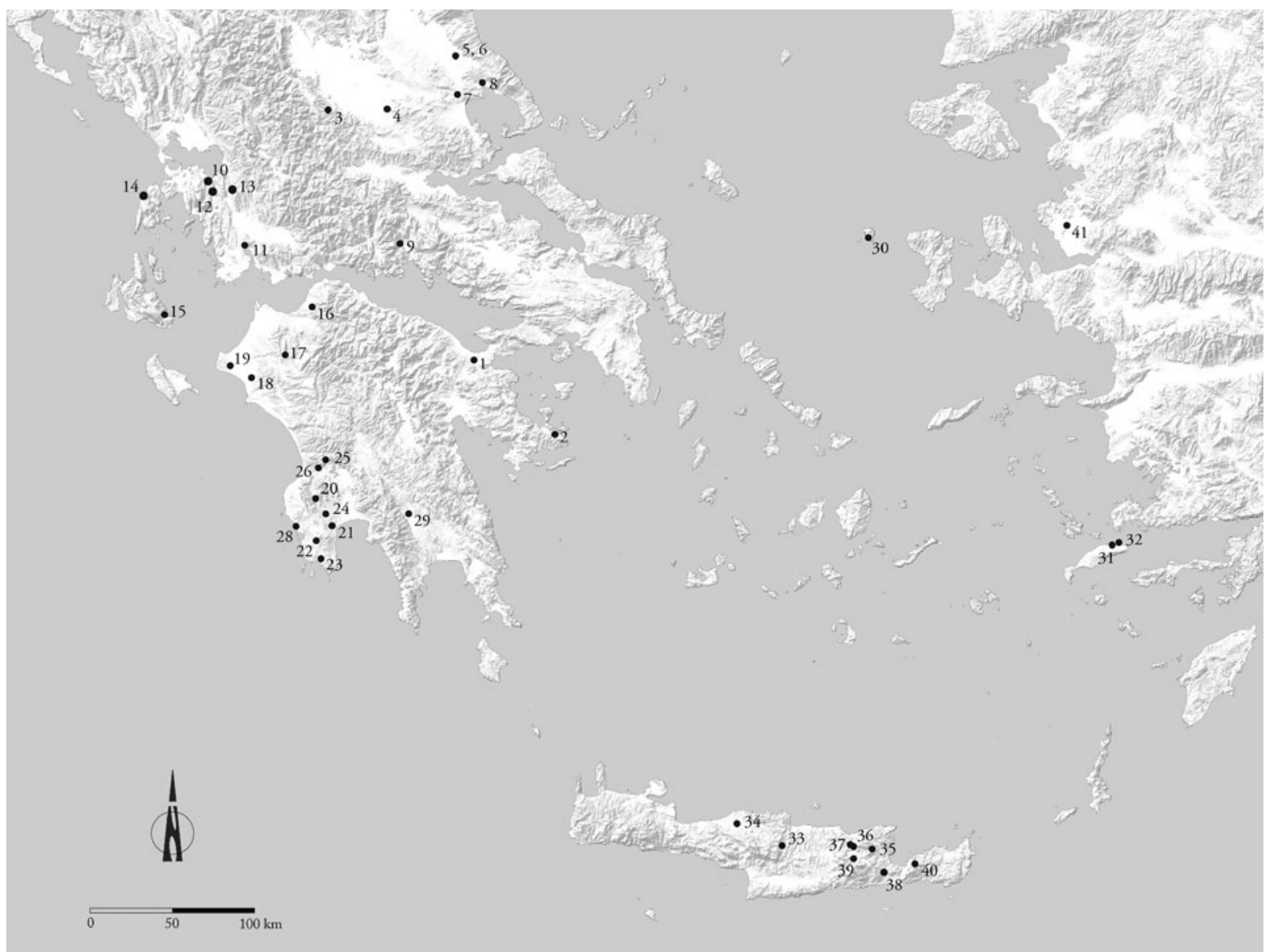

Map 4. Distribution of tholos and tholoid built tombs discovered in the last 25 years. 1. Ancient Corinth; 2. Megali Magoula; 3. Rachoula; 4. Koutroulou Magoula; 5. Koryphoula Kanalia; 6. Kanalia Tsingenina; 7. Aerino; 8. Volos, Kazanaki; 9. Amphissa; 10. Moschovi Loutrakiou; 11. Stamna; 12. Katouna Perganti; 13. Kechrinia Valtou; 14. Agios Nikitas; 15. Poros, Tzanata; 16. Petroto; 17. Portes; 18. Triantaphyllia Koryphi; 19. Vartholomio, Katsiveri; 20. Kephalovryso; 21. Nichoria Lakkoules; 22. Platanovrysi; 23. Kaplani; 24. Diodia; 25. Chalkias; 26. Ambelophyto; 28. Romanos; 29. Sparta Polydendro (Kozi); 30. Psara, Archontiki; 31. Kos, Mesaria/Giorgaras; 32. Kos town; 33. Krousonas; 34. Margarites; 35. Zenia Mirambello; 36. Karphi; 37. Kera Pediados; 38. Kalamafka; 39. Kaminaki; 40. Azorias; 41. Panaztepe.

of the different strands of the funerary archaeology of the southern Aegean during the LBA - where once we had 'appendices' containing specialized studies, we should now be aiming to offer an integrated interpretation of funeral archaeology: a social archaeology of death completely interwoven with the world of the living, ${ }^{4}$ with sound methodology and clear theoretical awareness of the problems at stake.

In what follows, I offer a brief survey and commentary on recent discoveries arranged by tomb type. In the last 25 years, 89 new tholos tombs out of more than 300 known examples (Map 4) have been discovered at 40 sites, some in regions and at sites where previously none was known: for example at Amphissa (ID4746), Corinth (ID2492, ID4503), Megali Magoula near Galatas (ID1935), Sparta Polydendro (Kozi) (ID2553), Archontiki on Psara (ID520, ID1285) and Kos (AR 45 [1998-1999] 107; 50 [2003-2004] 73). For some time it was thought that the region north of the Alpheios river in Elis, up to the borders with Achaea, behaved differently from adjacent regions, especially Messenia, where tholoi proliferate. Discoveries made there in recent years have now overturned this hypothesis: tholos tombs

\footnotetext{
${ }^{4}$ Although we now know more Mycenaean settlements than we did 25 years ago, the understanding of the relationship between cemeteries and settlements remains limited, as the
}

former continue to be mostly investigated as part of salvage excavations. A better integration of the two will yield fruitful results in the future. 
have been discovered at Portes (Kolonas 2009a), Triantaphyllia Koryphi (ID2509) and Vartholomio, Katsiveri (10m external diameter: ID1896; extensively treated by Christos Mantzanas in ADelt 64 [2009] Chr. 381-86; 65 [2010] Chr. 796-818). More tholoi have come to light in western Greece, for example at Kechrinia Valtou (ID2391), Katouna Perganti (between Tryphos and Katouna; $7.12 \mathrm{~m}$ diameter) ${ }^{5}$ and, for the first time, on Lefkas at Agios Nikitas (ID432).

The three regions with the highest numbers of tholoi in the LBA Aegean - Messenia, Thessaly and Crete - have continued to yield several new examples: for example at Platanovrysi (ADelt 56 [2001-2004] Chr. 419-20), Romanos (ID2571), Kephalovryso (ID324) and Ambelophyto (ID4339) in Messenia; at Kazanaki on the ring road of Volos (ID1102) and Rachoula near Karditsa (9m diameter: ID5662, ID6346, ID6404) in Thessaly; and at Margarites (Papadopoulou 2006), Kaminaki (ID2871, ID3572), Kalamafka (ID3571, ID4547), Kera Pediados (ID3575) and Azoria (ID184; Eaby 2010) ${ }^{6}$ on Crete.

An interesting development is the discovery of clusters of small tholos tombs at Aerino (Arachoviti 2000) and Koryphoula Kanalia (ID1039, ID4014, ID4017, ID5091) in eastern Thessaly near the gulf of Volos, which in terms of contents and funerary behaviour are similar to rock-cut chamber tombs or small and crudely built 'tholoid' chamber tombs in other regions (e.g. Palaiochori and Vaskina in Laconia or Lazarides in Aegina). It appears that the tholoid tombs at Panaztepe, now inland and near Izmir, but once set on the slopes of a small island in the Aegean,were inspired by similar practices or generated by similar considerations (social and/or geological) (Erkanal Öktü 2008). In eastern Thessaly, small LBA tholoi were built in Neolithic houses, as, for example, attested at Koutroulou Magoula (ID2902, ID5571) and Kanalia Tsingenina (ID1990, ID4013).

Although it is still widely believed that tholoi first developed in Messenia at the end of the Middle Bronze Age, recent discoveries in the Corinthia (ID2492, ID4503) and at Megali Magoula near Galatas (ID1935) suggest that this type may have started to spread across the Aegean earlier than previously thought (and possibly already in Late Helladic I). Equally important is the suggestion of Davis and Stocker (2015) that monumental tholoi may already have made an appearance at the end of the Middle Bronze Age (e.g. tholos IV at Pylos).

Chamber tombs form the most popular Late Bronze Age tomb type in the southern Aegean (Map 5 and Map 6). Of the ca. 4,000 examples, more than 809 have been discovered in the last 25 years at 124 sites. Extensive cemeteries of chamber tombs have come to light in several regions across Greece: for example at Voudeni (more than 80 examples: Kolonas 2009b) and Portes (30 examples: Kolonas 2009a) in Achaea, ${ }^{7}$ at Agia Triada in Elis (50 examples: Vikatou 2009), Kompotades in Phthiotis (54 examples since 2009: ID6354) and Sikyon in the Corinthia (about 20 chamber tombs: ID4516). At Vari Kamini (ID4979) in Attica, 45 chamber tombs and 13 pits were found some $30 \mathrm{~m}$ southeast of the Varkiza Mycenaean cemetery. Dating mostly to the 14th and 13th centuries BC, among the finds were 309 intact vessels. An important discovery is also the extensive cemetery at Kolikrepi, about $2 \mathrm{~km}$ east of Spata where 53 chamber tombs, at least three pit-caves and four double pits came to light. The first chamber tombs were built in Late Helladic I; i.e. they are the earliest known of this type in Attica. Use of the Kolikrepi cemetery continued to LH IIIC (Stathi and Psallida 2015).

Apart from the aforementioned extensive cemeteries, several other new sites have been discovered: for example at Mageiras Kioupia near Olympia (ID1899), Loutra Heraias in Arcadia (ID306), Peristeri in Laconia (ID314, ID2555), Aliveri on Euboea, ${ }^{8}$ Kentri Rousses near Ierapetra (ID6545) ${ }^{9}$ and Pilavtepe in

\footnotetext{
${ }^{5}$ Poster presentation by Olympia Vikatou and Vaso Tsantila at the Third International Interdisciplinary Colloquium, The periphery of the Mycenaean world, Lamia, 18-21 May 2018.

${ }^{6}$ I have refrained from including here the more numerous Late Minoan IIIC to Early Iron Age examples, which are exhaustively presented in the PhD of Melissa Eaby (2007).

7 Voudeni and Portes are among the best presented
}

Mycenaean archaeological tomb sites. Portes is also impressive for the variety of its funerary forms: built chamber tombs covered by tumuli, tholos tombs, pits/cists and chamber tombs.

8 https://www.culture.gr/el/Information/SitePages/view. aspx?nID $=2348$.

9 https://www.culture.gr/el/Information/SitePages/view. aspx?nID $=2339$ 


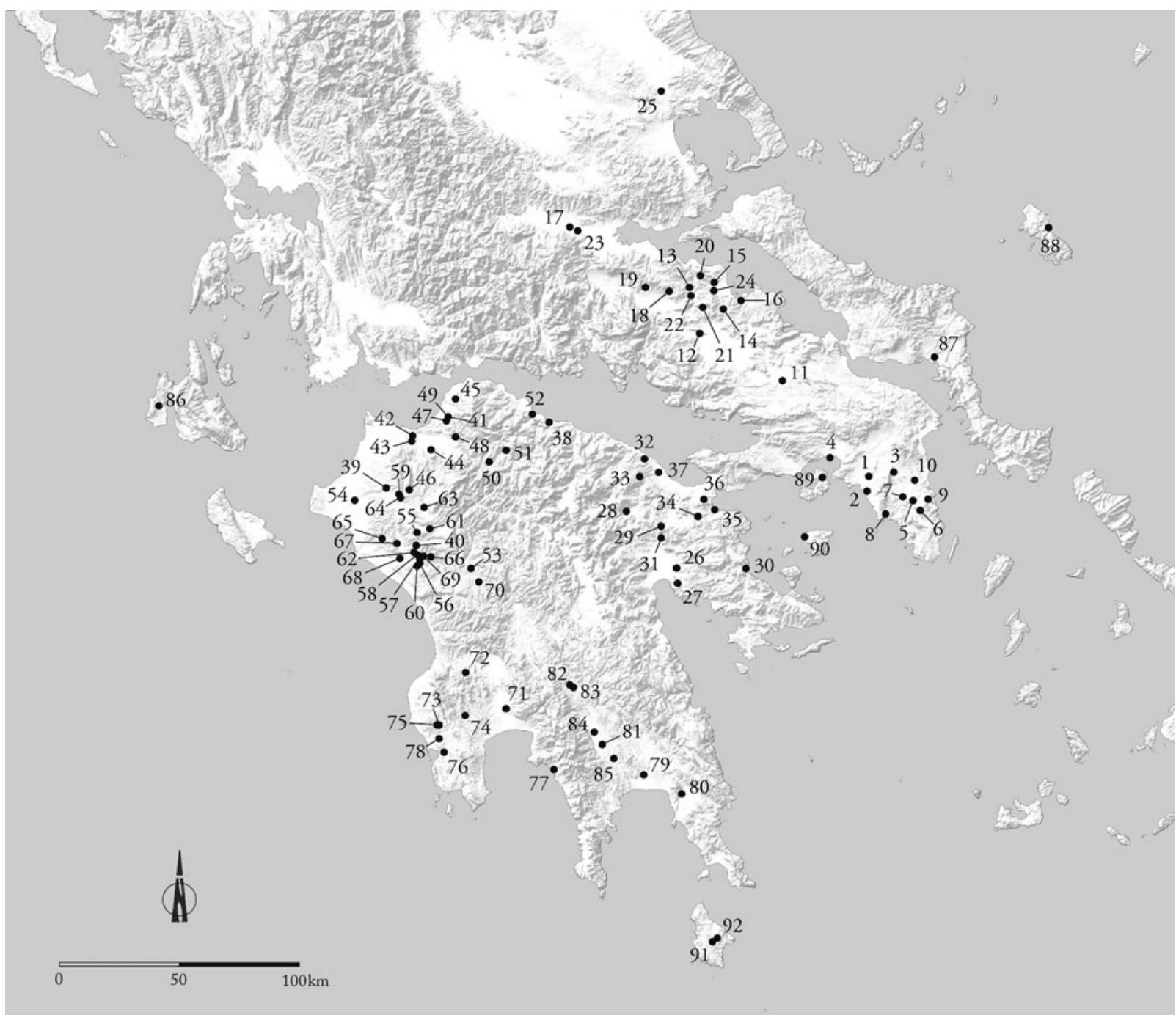

Map 5. Distribution of chamber tombs discovered in the last 25 years: central Greece and the Peloponnese. 1. Athenian Agora; 2. Akti Kalamakiou; 3. Glyka Nera; 4. Eleusis; 5. Markopoulo; 6. Merenda; 7. Vourvatsi; 8. Vari Kamini; 9. Porto Raphti; 10. Spata, Kolikrepi; 11. Thebes; 12. Prosilio; 13. Zeli Agios Georgios; 14. Kolaka, Kyrtone; 15. Megaplatanos; 16. Tragana; 17. Mexiates; 18. Elateia Alonaki; 19. Modi; 20. Golemi Agios Ioannis; 21. Exarchos; 22. Kalapodi Kokkalia; 23. Kompotades; 24. Spartia; 25. Velestino; 26. Panariti; 27. Aria Agios Vlasis; 28. Aidonia; 29. Nemea; 30. Ancient Epidauros Nera; 31. Mycenae; 32. Thalero; 33. Kryoneri, Panagia or Agios Nikolaos; 34. Athikia, Agios Nikolaos; 35. Kato Almyri; 36. Gyriza; 37. Sikyon; 38. Trapeza; 39. Daphni Lakkathela; 40. Chelidoni; 41. Krini Zoitada; 42. Spaliareika; 43. Kalamaki Elaiochoriou; 44. Mitopolis; 45. Voudeni; 46. Portes; 47. Kallithea, Laganidia and Rabadania; 48. Chalandritsa; 49. Krini, Agios Konstantinos; 50. Vrysari Kalavryton; 51. Vrysari, Goumenissa; 52. Nikoleika; 53. Loutra Heraias; 54. Tragano Markopoulou; 55. Persaina Goumero; 56. Koskinas, Lakkopholia; 57. Mageiras Kioupia; 58. Kafkania, Karavas; 59. Agraphidochori, Kotrona; 60. Olympia, New Museum; 61. Vouzani, Klindia; 62. Kafkania, Glinatses; 63. Agia Triada; 64. Latas Alonaki; 65. Vrochitsa; 66. Pefkes; 67. Arvanitis; 68. Strephi; 69. Kladeos Trypes; 70. Kakouraiika; 71. Antheia Ellinika; 72. Ano Englianos; 73. Volimidia; 74. Aristomenis, Trani Sykia; 75. Kato Rouga, Prophitis Elias; 76. Pyla; 77. Proastio; 78. Iklaina; 79. Peristeri; 80. Sykia; 81. Agios Vasileios; 82. Pellana Trypes; 83. Pellana, interchange; 84. Amyklai Spilakia; 85. Daphni Louria; 86. Palliki Skineas; 87. Aliveri; 88. Skyros Basales; 89. Salamis town; 90. Aegina town; 91. Kythera, Viaradika; 92. Kythera, Palaiopolis. 


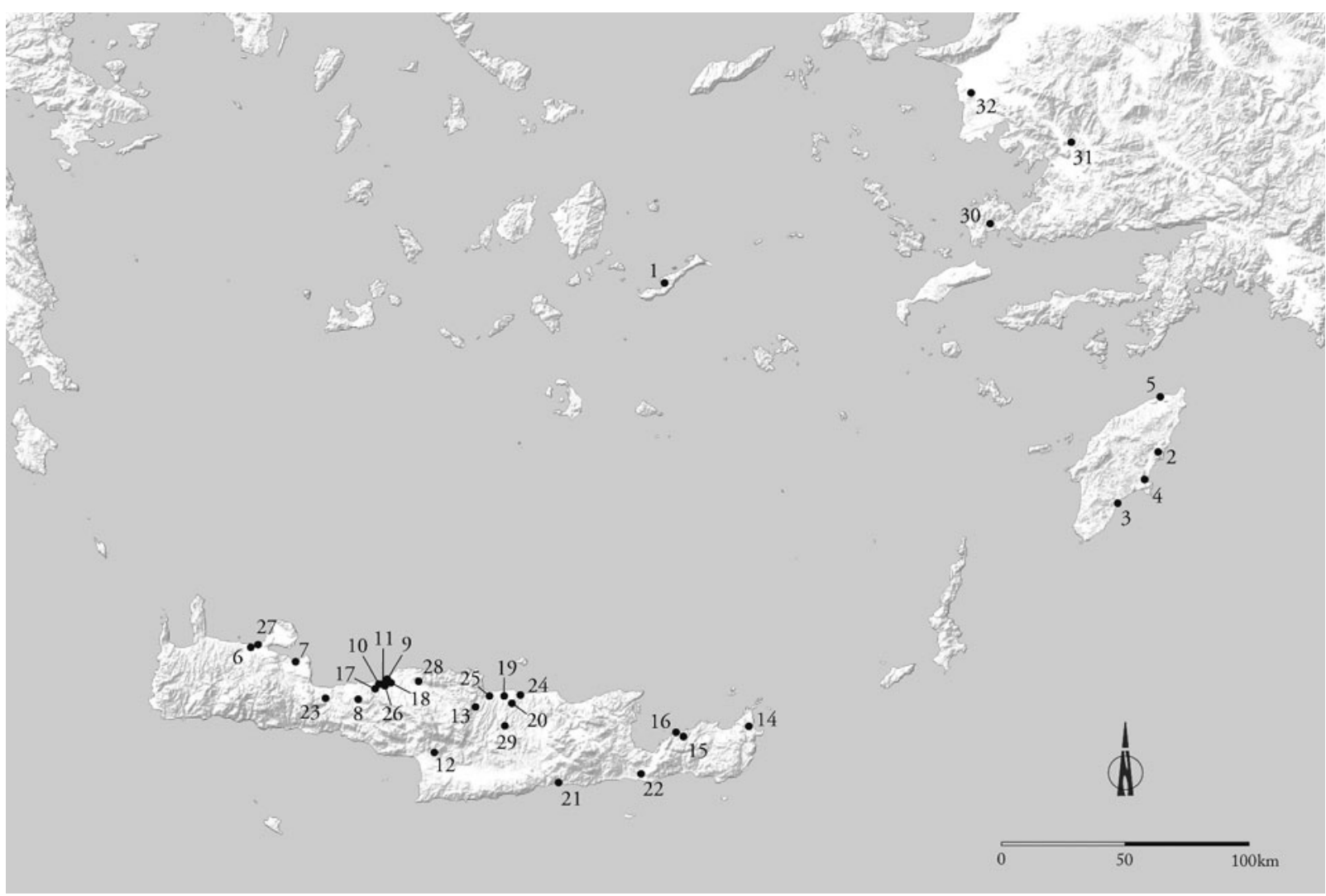

Map 6. Distribution of chamber tombs discovered in the last 25 years: Crete, islands, Asia Minor. 1. Amorgos Xylokeratidi; 2. Archangelos Vigli; 3. Gennadi; 4. Pylona; 5. Treis, Kremasti; 6. Aptera; 7. Kera, Kalyves; 8. Armenoi; 9. Sphakaki; 10. Pigi; 11. Pangalochori; 13. Moni Maleviziou; 14. Palaikastro; 15. Tourloti; 16. Mochlos; 17. Maroulas; 18. Magnesia; 19. Poros, Herakleio; 20. Knossos; 21. Keratokambos Viannou; 22. Kentri Rousses; 23. Kastellos; 24. Karteros, Agia Photeini; 25. Gazi; 26. Arsani; 27. Chania; 28. Melidoni, Kophinas hill; 29. Karnari Temenous; 30. Müskebi-Ortakent; 31. Pilavtepe, Milas; 32. Miletus Değirmentepe.

Milas, southwestern Turkey (Benter 2009; 2010), to name but a few. Work at well-established cemeteries has continued to yield several more chamber tombs: for example at Mycenae in the Argolid, at Ano Englianos (ID5104) and Antheia Ellinika (ID1501) in Messenia, Chania in Crete, ${ }^{10}$ Miletus Değirmentepe (Akat İslam and Aslan 2015) and Müskebi-Ortakent ${ }^{11}$ in southwestern Turkey.

At Aptera near Chania (ID1869), a chamber tomb was discovered some 150m northwest of five other Late Minoan IIIA2-B chamber tombs excavated in the late 1960s at Kalami. It was equipped with two underground chambers and its excavation yielded some 100 vessels dating from LM II to LM IIIA. The two chambers appear to be virtually contemporary. According to the excavator, Eleni Papadopoulou, it is possible that the tomb marks a transition between multi-chambered Minoan tombs and the more regular Mycenaean variety (ID1869).

Among the chamber tombs discovered in the last 25 years, there are also some monumental examples like the one discovered at Glyka Nera (Vorylla plot: ID2258), the two examples at Mageiras Kioupia near Olympia (ID1899), a third example at Mycenae Asprochoma (Palaiologou forthcoming) and tomb 15 at Antheia Ellinika (ID1501), second only in size to tomb 6 from the same site. The tombs at Prosilio (ID6170), a new site in northern Boeotia, belong to an extensive chamber-tomb cemetery most likely

${ }^{10}$ For example at Kouklaki, Rovithakis, Malephakis plots, Dimotiko Stadio and Dimokratias Street, since 1996; for the important Kouklaki cluster, see the detailed report by Maria Andreadaki-Vlasaki in ADelt 60 (2005) Chr. 1012-18; also,
Andreadaki-Vlasaki and Protopapadaki 2009: 152-65; Wiener 2015.

11 http://www.hurriyet.com.tr/ege/arkeoloji-muzesi-50yilini-kutladi-27533974. 
associated with ancient Orchomenos. The monumental tomb 2 excavated there in 2017 yielded the first intact burial - that of a man - in a chamber tomb of this type and size. With the number of undiscovered and unlooted archaeological contexts dwindling, the need for properly resourced and strategic fieldwork becomes ever more acute, especially if we are to learn more about the bioarchaeology and social archaeology of the deceased population of the Late Bronze Age Aegean.

Indeed, in recent years emphasis during the excavation of chamber tombs has been placed on improving the methodology and collection of data, and focusing on reconstructing the social archaeology of the population buried therein. This approach has already yielded significant results and better insights with regards to episodes of use and ritual practices, as well as a finer grasp of the manipulation of bones and objects by the living, as illustrated, for example, by the excellent ASCSA publications on the tombs at Agia Sotira and Mochlos mentioned above. In the past, tombs were frequently described as 'looted'. Although this may well be true in a number of instances, more careful excavation methodologies have started to reveal intentional 'disturbances' by the living, in the Late Bronze Age, as part of actions associated with visits to the grave (e.g. opening/closing ceremonies, preparation for new burial/reburial or to check the structural condition of the tomb). ${ }^{12}$ These finer approaches help us to understand not only what people placed in a particular grave (in terms of objects) but also what they did there and how they interacted with the structure, the burials and the totality of material deposited therein - all very important aspects for understanding site-based and regional attitudes to death as well as similarities and differences across periods and regions. ${ }^{13}$

Only three sites have yielded shaft graves in recent years (Map 7): the early Late Bronze Age 'warrior burial' at Plasi, Marathon, ${ }^{14}$ the Late Helladic II 'Griffin Warrior' burial at the Palace of Nestor in Pylos (ID5577) and the six Late Minoan II-IIIA1 shaft graves at Chania (Kouklaki plot, Isopedon Mazali). The discovery at Pylos was made in May 2015 on the resumption of excavations at the Palace of Nestor for the first time since 1969. The shaft grave, a stone-built chamber ( $c a .2 \mathrm{~m} \times 1.05 \mathrm{~m}$ and $1.5 \mathrm{~m}$ deep), yielded ca. 1,500 individual objects accompanying the extended burial of a single man who was 30-35 years old at death. The body had been buried in a wooden coffin. The bottom course of the chamber consisted of large ashlar blocks, perhaps repurposed from some earlier building on the acropolis. Various grave offerings had been placed in and on top of the coffin and in the shaft around it. These included stone and metal beads, other jewellery, seals, carved ivories, metal vessels of gold, silver and bronze, and bronze weapons. The four impressive gold signet rings and an agate seal with a 'combat' engraving of astonishing quality have been promptly published by Stocker and Davis (2017; Davis and Stocker 2016). It is also worth noting the almost complete absence of ceramics and the large amount of jewellery associated with an elite male burial (a practice also attested in chamber tomb 2 at Prosilio in Boeotia (ID6170), almost a hundred years later than the 'Griffin Warrior' burial).

The discoveries made in 2003-2005 (ID2004) at Isopedon Mazali (Kouklaki plot) next to the Church of St Paul and St Peter at Chania have added important new information for the funerary archaeology of Late Minoan II-IIIB Crete (see references in n. 10). The 53 Late Bronze Age tombs, revealed in an area of $1,680 \mathrm{~m}^{2}$, were of three different types: pit-caves (32 examples, largely unrobbed), chamber tombs (15 examples $)^{15}$ and six shaft graves. Grave goods in the shaft graves were relatively few: nine ceramic vessels and 12 items of bronze were recovered, along with items in other materials, but a large number of these came from the LM IIIA1 tomb 46 . The shaft $(1.4 \mathrm{~m} \times 2.9 \mathrm{~m}$ and $3 \mathrm{~m}$ deep $)$ was lined at the bottom with rough

12 For another notable instance, see the Kazanaki tholos tombs on the ring road of Volos: Adrymi-Sismani and Alexandrou 2009; Papathanasiou 2009; Galanakis 2016.

${ }^{13}$ Despite recent discoveries, the number of Late Helladic IIIIB chamber tombs remains low (fewer than 100) in a number of regions: for example in Aetoloakarnania, the Cyclades, Euboea, the Ionian islands, Phocis, Laconia, Messenia, Thessaly, the northeastern Aegean and western
Turkey. In contrast, chamber tombs proliferate in Achaea, Elis, the northeastern Peloponnese, Attica, Phthiotis, Crete and the Dodecanese (mostly Rhodes and Kos).

14 http://www.onalert.gr/stories/marathwnas-ta-prwtasumperasmata-gia-tn-tafo-tou-polemisth-tou-1600-px/55588

15 Chamber tomb 13 was found unlooted and contained several bronze objects, similar to tomb 14 at Zapher Papoura near Knossos. 


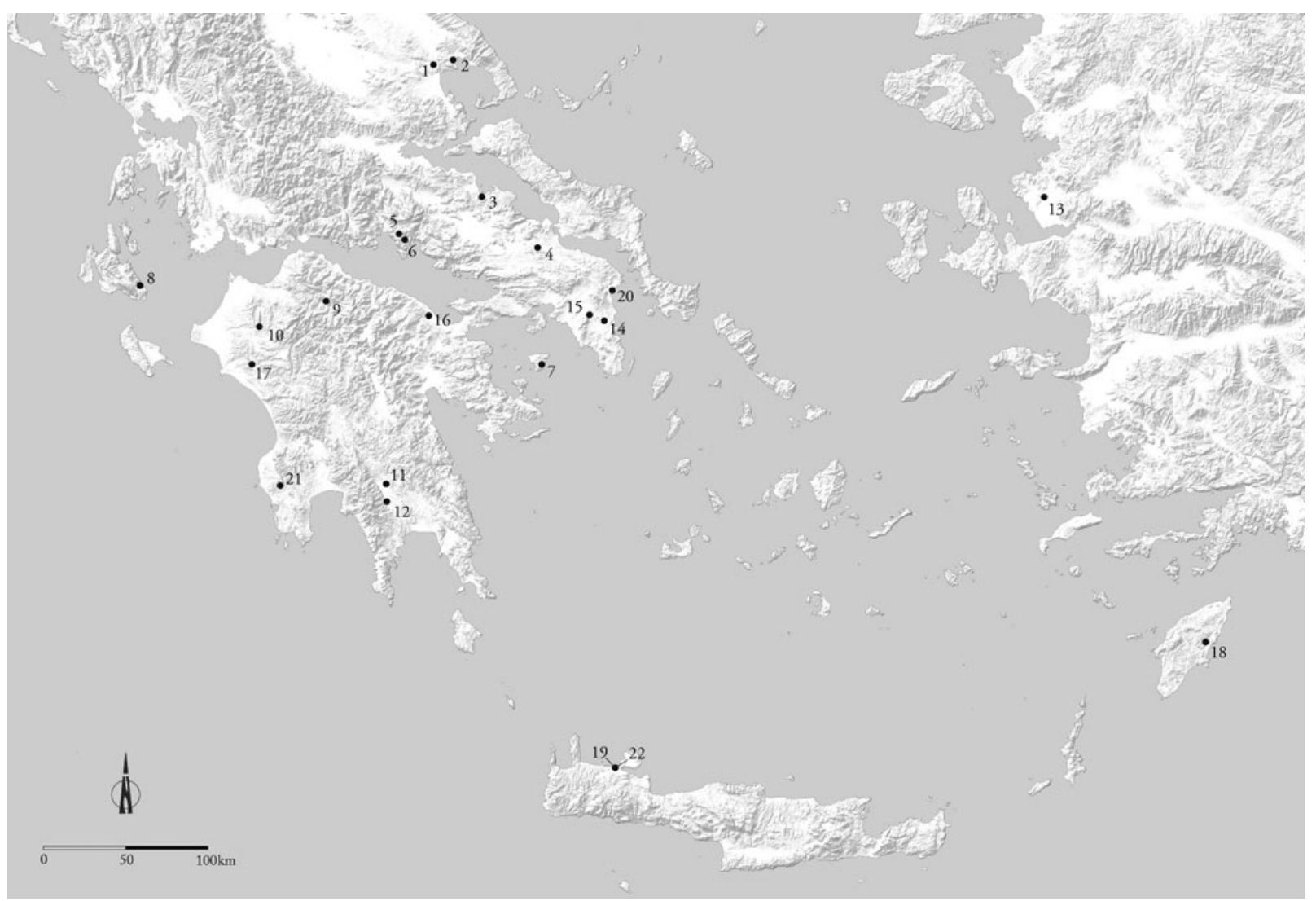

Map. 7. Distribution of built chamber tombs, pit-caves, double pits and shaft graves discovered in the last 25 years. (a) Built chamber tombs (including hybrids) and 'built graves' (ca. 21 at 13 sites): 1. Aerino; 2. Dimini; 3. Mitrou; 4. Eleon; 5. Sykia Desphinas; 6. Kastrouli; 7. Lazarides; 8. Poros, Tzanata; 9. Vrysari, Goumenissa; 10. Portes; 11. Sparta, Psychiko; 12. Agios Vasileios; 13. Panaztepe. (b) Pit-caves, double pit-caves, double pits (at least 54, probably more, at six sites): 14. Spata, Kolikrepi; 15. Glyka Nera; 16. Sikyon; 17. Arvanitis; 18. Agia Agathi Malonas; 19. Chania. (c) Shaft graves (eight at three sites): 20. Marathon, Plasi; 21. Ano Englianos; 22. Chania, Kouklaki plot.

masonry, producing a smaller burial chamber (roughly $1 \mathrm{~m} \times 2.2 \mathrm{~m}$ and $1.54 \mathrm{~m}$ high). Within lay a male (some 35 years old), tall and well built, with large facial features. Grave goods comprise a small piriform jar, a bronze vessel and razor, a cornelian seal and items echoing a 'military' status (i.e. a long sword with bone pommel and gold embellishments, three spearheads and several arrows). The combination of the three tomb types and the practices attested therein find their best parallel in the tombs at Knossos and especially the Zapher Papoura cemetery excavated in 1903-1904 by Arthur Evans and his team (Evans 1906).

The number of pit-caves and 'double pits' has recently increased significantly (Map 7) with new discoveries at Chania (32 examples as mentioned above, the earliest pit-cave dating to Late Minoan II and yielding a 'warrior burial'), at Kolikrepi near Spata (at least three examples: Stathi and Psallida 2015), Sikyon (ID4516) and Agia Agathi Malonas on Rhodes (six examples: ID3378, ID5594; Zervaki 2011; 2014). So far, these tombs, with more than 100 known examples, are most popular at Chania, followed closely by Knossos and the northeastern Peloponnese and Attica, than in other regions of the Aegean. No proper study of these tombs has taken place and with the new material now available, there is much that can be done. ${ }^{16}$

${ }^{16}$ For some recently discovered funerary 'hybrids', between a chamber tomb and a pit-cave, in Elis (Strephi and Arvanitis), see Lambropoulos et al. 2009. For other 'hybrids' (similar to the BCTs at Vaskina and Palaiochori in
Laconia, also upland locations), see the tombs at Sykia Desphinas (ID5083) and Kastrouli in Phocis, the form of which may have also been influenced by the local geology: AR 63 [2016-2017] 33; Sideris et al. 2017. 
Papadimitriou's excellent study (2001) of built chamber tombs (BCT) gathers together all known examples to $2001 .{ }^{17}$ In the last 25 years, 21 new BCTs at 13 sites have come to light (Map 7): for example at Portes in Achaea (Moschos 2000; Moschos and Gazis 2008; Kolonas 2009a), Vrysari Kalavryton (ADelt 67 [2012] Chr. 288-93), Eleon in Boeotia (ID5065, ID5442, ID6179) and the elaborate tomb 73 Mitrou in Phthiotis (ID806, ID1359, ID2684, ID3062, ID4214; AR 56 [2009-2010] 92). BCTs, as already suggested by Papadimitriou, appear to be a product of the funerary architectural competition, experimentation and elaboration observed across several regions and sites in the southern Aegean during the late Middle Bronze Age and early Late Bronze Age.

Most of the BCTs appear to express the agendas of emerging local elites, and a number of early specimens include architectural refinements while their location was emphasized further by enclosure walls and/or the construction of a tumulus marking their position. One such impressive example, a 'grave rectangle' instead of a 'grave circle', is the enclosure called the 'Blue Stone Structure' (BSS) at Eleon (ID5065, ID5442, ID6179), so named because of the polished blue limestone used to cap a large, rectangular perimeter wall. The structure was topped with a mound of clay, contained two standing grave stelae and marked an Early Mycenaean cemetery of some significance dating to the formative period of Mycenaean society, $c a$. 17th century BC. Within, several graves have been investigated, including a number of BCTs, the excavation of which will undoubtedly enhance further our understanding of early Late Bronze Age practices.

$\mathrm{BCT}$ are distributed as far north as Thessaly (as also suggested by the recent discovery of a BCT, $c a$. $3.8 \mathrm{~m} \times 2.7-3.3 \mathrm{~m}$, at Dimini) ${ }^{18}$ and as far south as the southern Peloponnese (e.g. the BCT at Psychiko in Sparta town: ID1938). These tombs continued to be built in Late Helladic IIIA; see, for example, the BCTs at Aerino ${ }^{19}$ and the Beis plot at Dimini in Thessaly (ID5094), and the tombs at Lazarides on Aegina (Efstratiou and Polychronakou-Sgouritsa 2016). Some of these examples are also difficult to classify by our modern typologies as they share features of tholos architecture. Caution is needed, therefore, when working with 'types', as we should assess the behaviour of these tombs locally (at a site level) and regionally before comparing them across the Aegean in a strict typological fashion. After all, these 'types' are modern analytical categories and may not reflect how they were perceived by their original builders and users.

The second-largest category of tombs that has come to light in recent years, with some 705 examples at 54 sites, comprises pits, cists and other 'simple' graves (Map 8). The term 'simple' is certainly problematic, as it might make us think that these tombs were socially and politically 'inferior' to other more complex (architecturally and artefactually speaking) structures. Humble as most of these tombs may look, they should be assessed locally and regionally before being classified generically as 'simple', not least because some clearly had a more complex life than the term suggests and could have formed the focus of significant social actions.

Unfortunately, 'simple' graves are often superficially reported. Yet they are common and widely distributed, and their discovery in large numbers in recent years marks a considerable increase on the $c a$. 1,200 'simple graves' recorded in Kazimierz Lewartowski's important study (2000). The single most significant concentration of these tombs is the $c a$. 160 tombs at Archontiki on Psara: all cists with the exception of one tholos tomb (ID520, ID1285; AR 51 [2004-2005] 90). Pits, cists and other 'simple' graves are widely attested - with the exception of Crete, where they are rare. They appear to be frequent in the early Late Bronze Age on mainland Greece and during Late Helladic IIIA-B on the outskirts of the palatial world or in relatively remote areas, which also favour these types geologically (from Epirus and the area of Kozani, Haliakmon river and Platamonas in the north, ${ }^{20}$ to several sites in the upland Peloponnese, e.g. Vaskina Socha: ID2420).

${ }^{17}$ As I include examples from the last 25 years, there is some overlap with the BCTs already mentioned in Papadimitriou's 2001 study.

$18 \mathrm{https}$ //e-thessalia.gr/megalos-omadikos-tafos-apokalyfthike-sto-dimini/.

19 The material from the Aerino tombs is on display in the Volos Archaeological Museum and there are also very good information panels on site: http://efamagvolos.culture.gr/ Aerino\%20ODHGOS.pdf by Polyxeni Arachoviti.

20 This brief survey does not include tombs from northern Greece with 'Mycenaean' or 'Mycenaeanizing' material, of which a proper study would be useful. For an intriguing discovery from northern Greece, see Valla et al. 2013 (Phaia Petra, eastern Macedonia). 


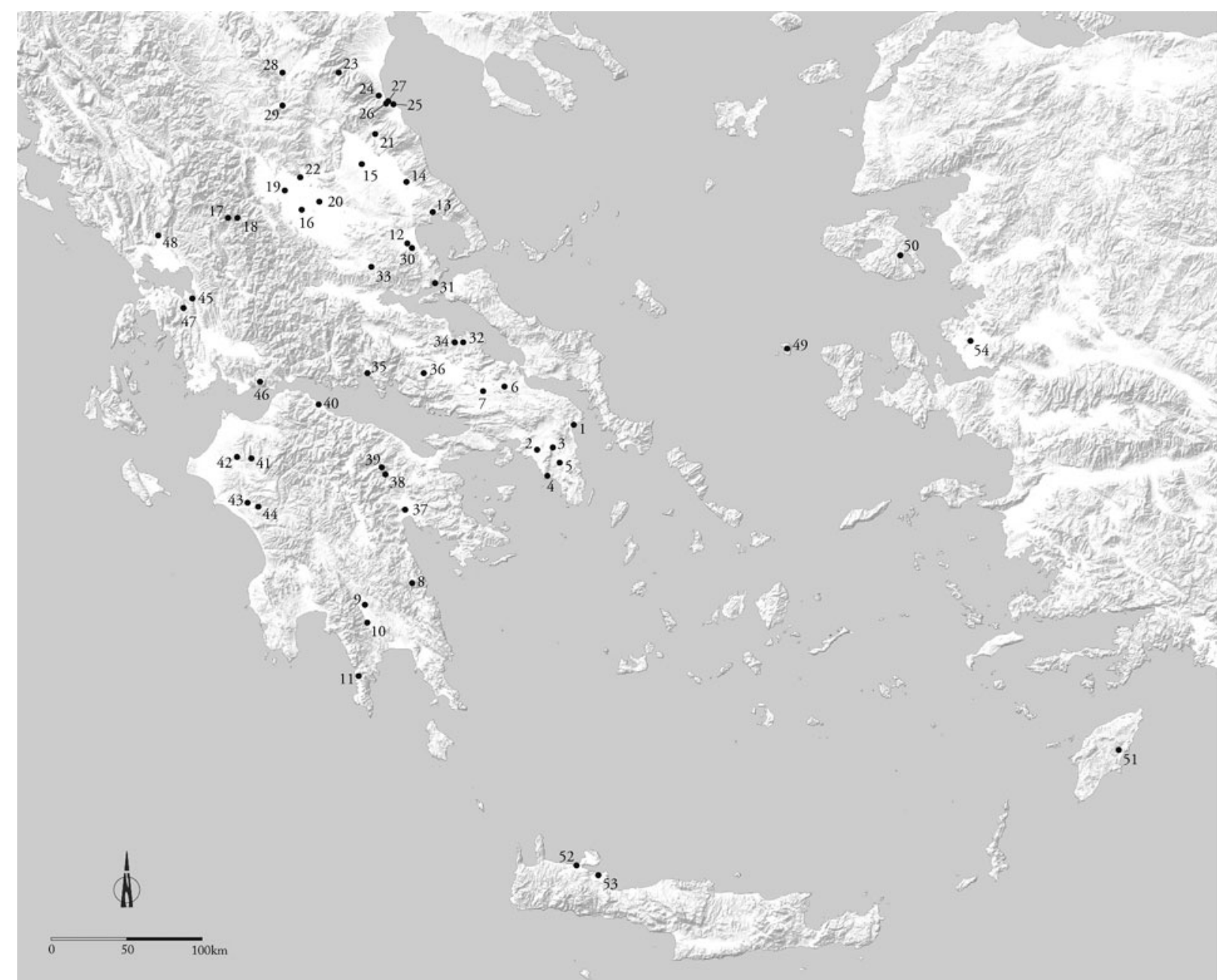

Map 8. Distribution of 'simple graves' (mostly pits, cists and other tombs) discovered in the last 25 years. 1. Marathon, Plasi; 2. Athenian Agora; 3. Glyka Nera; 4. Vari Kamini; 5. Vourvatsi; 6. Eleon; 7. Thebes; 8. Vaskina Socha; 9. Sparta Polydendro (Kozi); 10. Agios Vasileios; 11. Xagounaki; 12. Almyros-Halos Agrielia; 13. Kazanaki; 14. Koryphoula; 15. Gentiki; 16. Prodromos; 17. Palaiokastro Petrotou; 18. Agriokeraso Karyas; 19. Agnantero; 20. Ermitsi; 21. Makrychori; 22. Petroto; 23. Spathes, Agios Dimitrios; 24. Leivithra; 25. Neoi Poroi Pigi Athinas; 26. Platamonas, Pigi Artemidos; 27. Platamonas, Rema Xydias; 28. Aiani Livadia; 29. Logas Elatis; 30. Voulokalyva; 31. Glypha Phanos, Antron; 32. Proskynas; 33. Neochori, Mount Oeta; 34. Mitrou; 35. Kirrha; 36. Prosilio; 37. Argos; 38. Agia Eirene; 39. Asprokambos Zoodochos Pigi; 40. Aigion; 41. Portes; 42. Daphni Lakkathela; 43. Strephi; 44. Olympia, New Museum ; 45. Kouvaras; 46. Chania, Gavrolimnis; 47. Katouna Perganti; 48. Kokkino Lithari; 49. Psara, Archontiki; 50. Dipi Lesvos; 51. Agia Agathi Malonas; 52. Chania; 53. Kera, Kalyves; 54. Panaztepe.

The tombs at the North Cemetery at Agios Vasileios (ID6125) illustrate the complexity of mortuary practices in 'simple' graves (typologically speaking) in southern Greece at the onset of the Mycenaean era, when formal cemeteries, larger tombs, richer burials and a more complex ritual sequence involving multiple interments were systematically introduced. Drawing on current advances in archaeothanatology, forensic science and analysis of commingled remains, the 2016 publication by Ioanna Moutafi and Sofia Voutsaki offers an integrated approach which aims to reconcile archaeological theory with current methodological advances in bioarchaeology and funerary taphonomy and seeks to reconstruct, quite convincingly, funerary activities in far greater detail than has been done previously in order to observe fully variation and change, and, ultimately, understand how this considerable variation may inform us about the redefinition of social relations at death or shifting notions of the self. This important study demonstrates the considerable extent of variation in funerary disposal and secondary treatment during this transitional period, which, if we were to study only the objects from these graves, we would not have been able to 
identify. For Moutafi and Voutsaki, this variation reflects the transformation of society at Agios Vasileios: from narrower (possibly household-based) associations to increasingly wider concepts of lineage and descent as well as tensions between tradition and innovation at a site level.

Another significant recent discovery is that of a 'warrior burial' in a cist tomb at Kouvaras (ID434) on the height of Rachouli, north of Lake Ozerou in Aetoloakarnania, in a strategic location overlooking the pass from the interior of Akarnania to the gulf of Ambrakia (Stavropoulou-Gatsi et al. 2012). In addition to four 14th-century BC ceramic vessels, the tomb contained valuable and sometimes unique offerings offensive and defensive weapons, a gold kylix with a high stem of a Late Helladic IIIC ceramic type and a bronze tripod embellished with new features akin to later developments (mixed handles, curved supports between the legs and body of the lebes). The offensive weaponry included a very long $(0.94 \mathrm{~m})$ bronze Naue II sword with gold wire wrapped around the handle, a further bronze sword of Sandars type F with a bone handle, a leaf-shaped spearhead of Mycenaean type, an arrowhead with a long tang and a bimetallic knife of Italian origin or type (the blade is iron and the handle bronze with bone inlay held with bronze nails). The defensive weaponry includes a pair of greaves with wire points for lacing of a type known from Calabria to Enkomi.

With regards to somewhat unexpected discoveries, one can list the 'Mycenaean ossuary' at Xagounaki near Alepotrypa Cave, Diros (ID4889). In the overlying levels was a round bone enclosure, $4 \mathrm{~m}$ in diameter, defined by field stones and with a pebble floor. A large quantity of human skeletal remains representing tens of individuals in secondary deposition was collected from the floor surface, together with characteristic Late Helladic III objects (e.g. pottery, beads and a dagger). Given the scarcity of Mycenaean sites in the immediate vicinity of the cave, this is indeed an extraordinary discovery. At the fourth Archaeological work in Crete meeting, Michalis Milidakis and Eleni Papadopoulou (2016) offered a preliminary report on their remarkable discovery at Kera near Kalyves (Chania, Crete) of two small chamber tombs, two pithos burials and some 104 'ritual pits' dating to Late Minoan IIIB-C.

Despite the long economic crisis, the Greek Archaeological Service with all its associated staff, the Greek universities and research institutes, and their foreign colleagues have all continued to make significant discoveries, bringing to light contexts that shape our discourse and expand our knowledge of Late Bronze Age funerary practices and attitudes to death across the Aegean. They have also continued to train the next generation of field archaeologists, necessary for the successful continuation of research. Technological advances, our research questions and finer methodologies help us nowadays to collect better-quality data, which, in the years to come, will offer a deeper understanding of the six centuries that shaped Aegean affairs in the later second millennium BC, socially and politically, helping us to move beyond issues of social organization to more nuanced aspects of funerary practice, advancing our knowledge of the multivalent roles played by burials within ancient societies.

Despite the increasing costs and demands, in human power and expertise, in organizing a well-tuned excavation, Aegean archaeology is now richer in terms of knowledge, methods and practices - and so is the funerary archaeology of the Late Bronze Age, which includes one of the finest corpora for study and debate. What surprises will the next 25 years hold for the field? We wait with great anticipation.

\section{Bibliography}

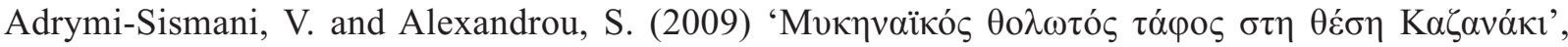
AEThSE 2 (2006), 133-49

Akat İslam, H. and Aslan, A. (2015) 'Milet Nekropolü, Değirmentepe mevkii kazı çalışmaları (20122013)', in A. Özme (ed.), Müze Çalışmaları ve Kurtarma Kazıları Sempozyumu 23, 377-96 Aktypi, K. (2017) The Mycenaean Cemetery at Agios Vasileios, Chalandritsa, in Achaea (Oxford)

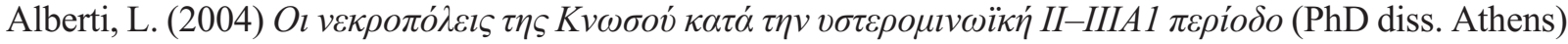
Alram-Stern, E., Blakolmer, F., Deger-Jalkotzy, S., Laffineur, R. and Weilhartner, J. (2016) Metaphysis: Ritual, Myth and Symbolism in the Aegean Bronze Age (Aegaeum 39) (Leuven)

Andreadaki-Vlasaki, M. and Protopapadaki, E. (2009) 'Kouklaki excavation', in M. Andreadaki-Vlazaki (ed.), Khania (Kydonia): A Tour to Sites of Ancient Memory (Chania) 152-65 


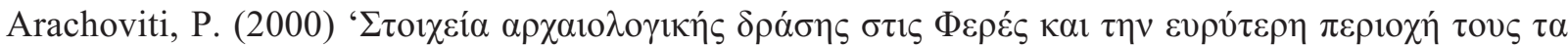

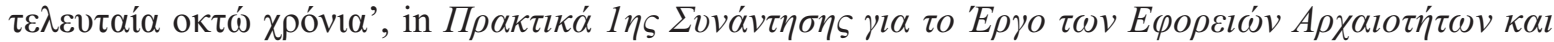

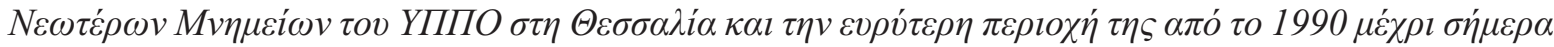
(Volos) 355-72

Benter, M. (2009) 'Das mykenische Kammergrab von Pilavtepe', in F. Rumscheid (ed.), Die Karer und die Anderen (Bonn) 349-58

- (2010) 'Milas'taki Pilavtepe Miken oda mezar1', Belleten 74.270, 343-50

Boyd, M.J. (2002) Middle Helladic and Early Mycenaean Mortuary Practices in the Southern and Western Peloponnese (Oxford)

Cavanagh, W. and Mee, C. (1998) A Private Place: Death in Prehistoric Greece (Jonsered)

Dakouri-Hild, A. and Boyd, M.J. (eds) (2017) Staging Death: Funerary Performance, Architecture and Landscape in the Aegean (Berlin)

Davis, J.L. and Stocker, S.R. (2015) 'Crete, Messenia, and the date of Tholos IV at Pylos', in C.F. Macdonald, E. Hatzaki and S. Andreou (eds), The Great Islands: Studies of Crete and Cyprus Presented to Gerald Cadogan (Athens) 175-78

- (2016) 'The lord of the gold rings: the Griffin Warrior of Pylos', Hesperia 85, 627-55

Dickinson, O.T.P.K., Papazoglou-Manioudaki, L., Nafplioti, A. and Prag, A.J.N.W. (2012) 'Mycenae revisited part 4: assessing the new data', BSA 107, 161-88

Eaby, M. (2007) Mortuary Variability in Early Iron Age Cretan Burials (PhD diss. North Carolina at Chapel Hill)

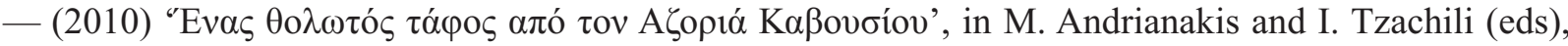

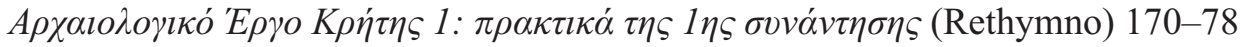

Eerbeek, J. (2014) The 'Mycenaeans' in the South-Eastern Aegean Revisited (PhD diss. Amsterdam)

Effinger, M. (1996) Minoischer Schmuck (Oxford)

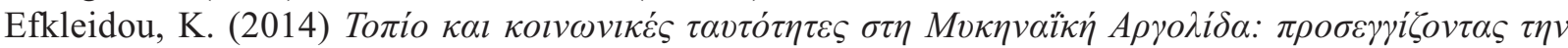

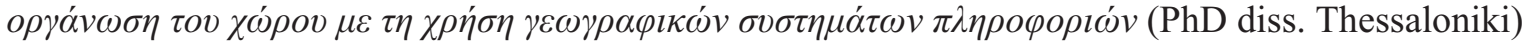

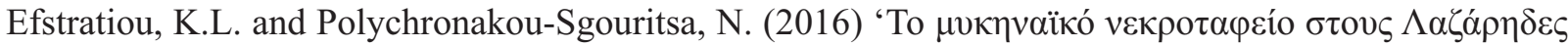

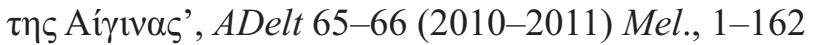

Erkanal-Öktü, A. (2008) 'The Late Bronze Age cemeteries of Panaztepe', in A. Erkanaal-Öktü, S. Gunel and U. Deniz (eds), Batı Anadolu ve Doğu Akdeniz Geç Tunç Çă̆ı Kültürleri Üzerine Yeni Araştırmalar (Ankara) 69-90

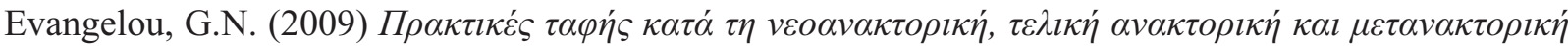

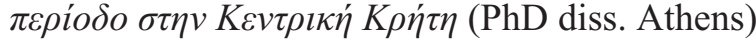

Evans, A.J. (1906) 'The Prehistoric tombs of Knossos', Archaeologia 59, 391-562

Fitzsimons, R.D. (2006) Monuments of Power and the Power of Monuments: The Evolution of Elite Architectural Styles at Bronze Age Mycenae (PhD diss. Cincinnati).

Galanakis, Y. (2007) A Study of Late Bronze Age Tholos Tombs in the Aegean 1700-1200 BC (DPhil diss. Oxford)

- (2016) 'Fire, fragmentation and the body in the Late Bronze Age Aegean', in M. Mina, S. Triantaphyllou and Y. Papadatos (eds), Embodied Identities: An Archaeology of Prehistoric Bodies and Embodied Identities in the Eastern Mediterranean (Oxford and Philadelphia) 189-96

Gallou, C. (2005) The Mycenaean Cult of the Dead (Oxford)

Georgiadis, M. (2003) The South-Eastern Aegean in the Mycenaean Period: Islands, Landscape, Death and Ancestors (Oxford)

Giannopoulos, T. (2008) Die letzte Elite der mykenischen Welt: Achaia in mykenischer Zeit und das Phänomen der Kriegerbestattungen im 12.-11. Jahrhundert v. Chr. (Bonn)

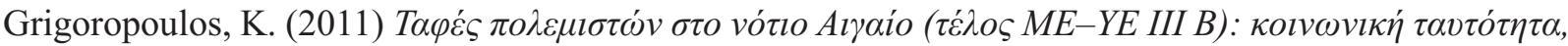

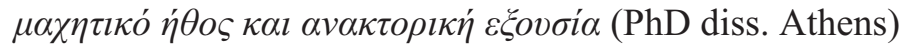

Hristova, P.D. (2010) Masks and People: Reconstructing the Early Mycenaean Funerary Ritual through Archaeological Images and Context (PhD diss. UCLA) 
Iezzi, C.A. (2005) Regional Differences in the Health Status of Late Bronze Age Mycenaean Populations from East Lokris, Greece (PhD diss. Buffalo, New York)

Jazwa, C.S. and Jazwa, K.A. (2017) 'Settlement ecology in Bronze Age Messenia', Journal of Anthropological Archaeology 45, 157-69

Jones, O.A., van der Plicht, J., Papazoglou-Manioudaki, L. and Petropoulos, M. (2018) 'Timing is everything: radiocarbon dating multiple levels in the Mycenaean tholos tomb of Petroto, Achaia, Greece', STAR: Science \& Technology of Archaeological Research 3:2, 456-65, https://doi.org/10.1080/20548923.2018.1428408

Karantzali, E. (2001) The Mycenaean Cemetery at Pylona on Rhodes (Oxford)

Karetsou, A. and Girella, L. (2015) Kalochorafitis: Two Chamber Tombs from the LM IIIA2-B Cemetery: A Contribution to Postpalatial Funerary Practice in the Mesara (Padua)

Karkanas, P., Smith, R.A.K., Dabney, M.K and Wright J.C. (2012) 'The geoarchaeology of Mycenaean chamber tombs', Journal of Archaeological Science 39.8, 2722-32

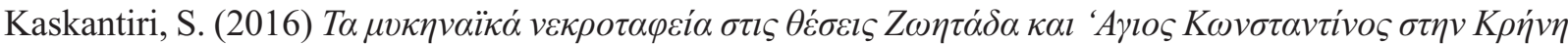
$\Pi \alpha \tau \rho \omega ́ v$ (PhD diss. Ioannina)

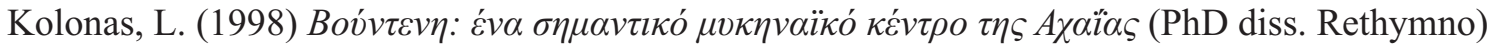

- (2009a) Network of Visitable Mycenaean Settlements and Cemeteries in the Prefecture of Patras (Athens)

- (2009b) Voudeni: An Important Site of Mycenaean Achaia (Athens)

Konstantinidi-Syvridi, E. (2018) 'Mycenae, Shaft Grave III: tomb of the high priestess?', Journal of Prehistoric Religion 26, 47-60

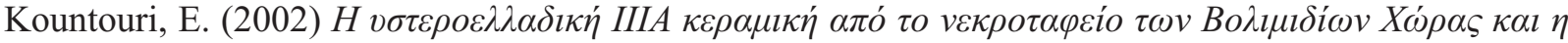

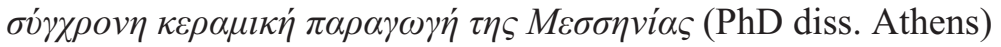

Lambropoulos S., Mountzouridis, P. and Nikolentzos, K. (2009) 'Hybrid burial monuments of the Late Bronze Age in two recently excavated sites in Elis (Strephi and Arvaniti)' in H. Cavanagh, W.G. Cavanagh and J. Roy, J. (eds), Honouring the Dead in the Peloponnese: Proceedings of a Conference held at Sparta 23-25 April 2009 (Centre for Spartan and Peloponnesian Studies Online Publication 2) (Nottingham) https://www.nottingham.ac.uk/csps/resources/open-access/hounouring-the-dead.aspx

Leith, K.E. (2013) Expressions of Gender in Mortuary Behaviour from Middle Helladic and Mycenaean Burial Samples in the Aegean (PhD diss. UCL)

Lewartowski, K. (2000) Late Helladic Simple Graves: A Study of Mycenaean Burial Customs (Oxford)

Löwe, W. (1996) Spatbronzezeitliche Bestattungen auf Kreta (Oxford)

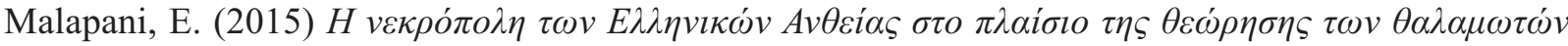

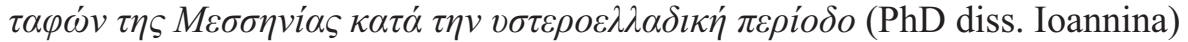

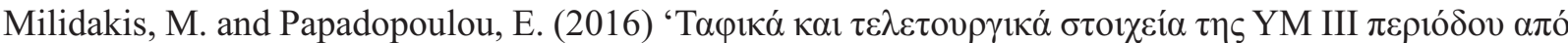

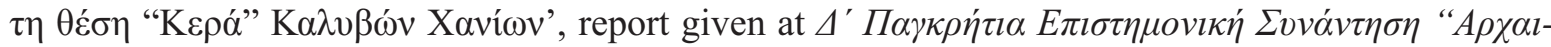

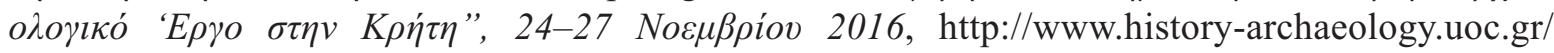
files/items/2/2841/aek4_perilipseis.fin.pdf

Mina, M., Triantaphyllou, S. and Papadatos, Y. (eds) (2016) An Archaeology of Prehistoric Bodies and Embodied Identities in the Eastern Mediterranean (Philadelphia)

Moschos, I. (2000) 'Prehistoric tumuli at Portes in Achaea: first preliminary report', Proceedings of the Danish Institute at Athens 3, 9-49

Moschos, Y. and Gazis, M. (2008) 'The Late Helladic cemetery of Portes in the northwest Peloponnese', in Y. Tzedakis, H. Martlew and M.K. Jones (eds), Archaeology Meets Science: Biomolecular Investigations in Bronze Age Greece: The Primary Scientific Evidence 1997-2003 (Oxford) 281-94

Moutafi, I. (2015) Towards a Social Bioarchaeology of the Mycenaean Period: A Multi-disciplinary Analysis of Funerary Remains from the Late Helladic Chamber Tomb Cemetery of Voudeni, Achaea, Greece (PhD diss. Sheffield)

Moutafi, I. and Voutsaki, S. (2016) 'Commingled burials and shifting notions of the self at the onset of the Mycenaean era (1700-1500 BCE): the case of the Ayios Vasilios North Cemetery, Laconia', Journal of Archaeological Science Reports 10, 780-90 
Müller, S. (1995) The Mycenaean Cemetery at Medeon in Phokis: Architecture and Grave Goods (PhD diss. Lyon 2)

Murray, S.C. (2018) 'Imported exotica and mortuary ritual at Perati in Late Helladic IIIC east Attica', AJA $122,33-64$

Nafplioti, A. (2007) Population Bio-cultural History in the South Aegean during the Bronze Age (PhD diss. Southampton)

- (2009) 'Mycenae revisited part 2: exploring the local versus non-local geographical origin of the individuals from Grave Circle A: evidence from strontium isotope ratio (87 $\mathrm{Sr} / 86 \mathrm{Sr})$ analysis', $B S A$ 104, 279-91

- (2011) 'Tracing population mobility in the Aegean using isotope geochemistry: a first map of local biologically available $87 \mathrm{Sr} / 86 \mathrm{Sr}$ signatures', Journal of Archaeological Science 38.7, 1560-70

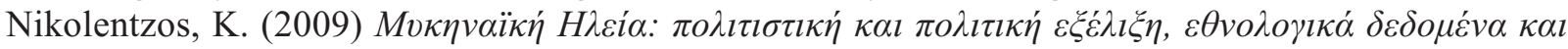
$\pi \rho \circ \beta \lambda \dot{\eta} \mu \alpha \tau \alpha$ (PhD diss. Athens)

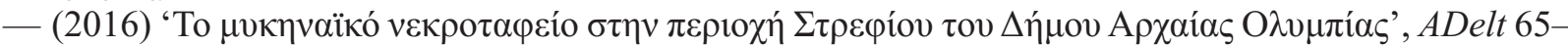
66 (2010-2011) Mel., 163-204

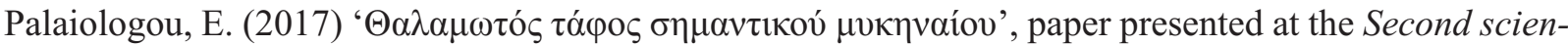
tific meeting: archaeological work in the Peloponnese’ (AWOP2), 1-4 November 2017 (Kalamata)

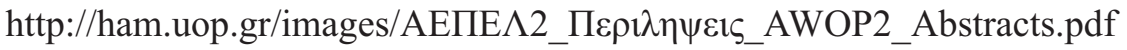

Papadimitriou, N. (2001) Built Chamber Tombs of Middle and Late Bronze Age Date in Mainland Greece and the Islands (Oxford)

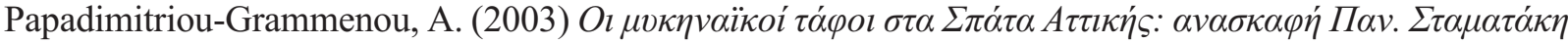
(1877) (PhD diss. Athens)

Papadopoulos, T.J. and Kontorli-Papadopoulou, L. (2014) Vravron: The Mycenaean Cemetery (Uppsala) Papadopoulos, T.J. and Papadopoulou-Chrysikopoulou, E. (2017) Excavations at the Mycenaean Cemetery at Aigion 1967: Rescue Excavations by the Late Ephor of Antiquities, E. Mastrokostas (Oxford)

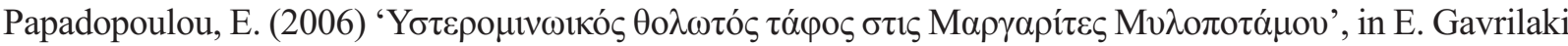

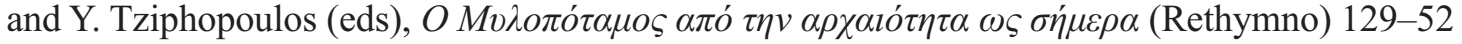

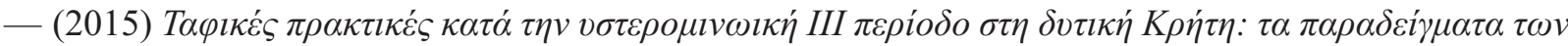

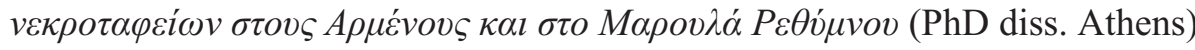

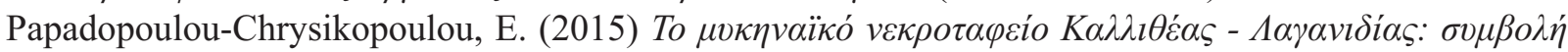

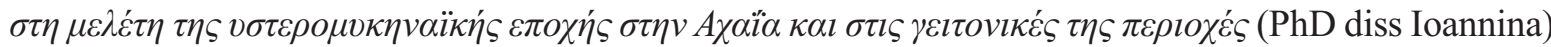

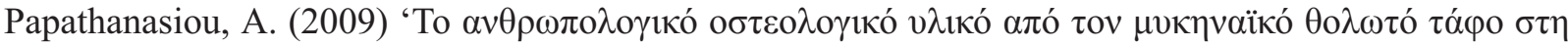

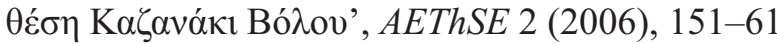

Papazoglou-Manioudaki, L., Nafplioti, A., Musgrave, J.H. and Prag, A.J.N.W. (2010) 'Mycenae revisted part 3: the human remains from Grave Circle A at Mycenae: behind the masks: a study of the bones of Study Graves I-V', BSA 105, 157-224

Papazoglou-Manioudaki, L, Nafplioti, A., Musgrave, J.H., Neave, R.A.H., Smith, D. and Prag, A.J.N.W. (2009) 'Mycenae revisited part 1: the human remains from Grave Circle A: Stamatakis, Schliemann and two new faces from Shaft Grave VI', BSA 104, 233-77

Pappi, E. and Isaakidou, V. (2015) 'On the significance of equids in the Late Bronze Age Aegean: new and old finds from the cemetery of Dendra in context', in A.-L. Schallin and I. Tournavitou (eds), Mycenaeans up to Date: The Archaeology of the North-eastern Peloponnese: Current Concepts and New Directions (Stockholm) 469-81

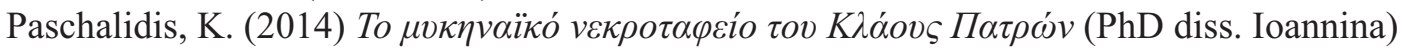

Pelon, O. (1998) 'Les tombes circulaires dans l'Égée de l'âge du Bronze: état des recherches sur les tombes à tholos', TOPOI 8, 95-158

Pomadère, M. (2007) Les enfants dans le monde égéen, du Néolithique au début de l'Âge du Fer (PhD diss. Paris I-Panthéon Sorbonne)

Preston, L.J. (2000) A Mortuary Approach to Cultural Interaction and Political Dynamics on LMII-IIIB Crete (PhD diss. UCL) 
Privitera, S. (2013) Principi, pelasgi e pescatori: l'Attica nella tarda età del Bronzo (Athens)

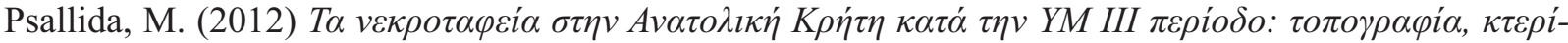
$\sigma \mu \alpha \tau \alpha, \tau \alpha \varphi \imath \kappa \varepsilon ́ \varsigma \pi \rho \alpha \kappa \tau \imath \kappa \varepsilon ́ \varsigma(\mathrm{PhD}$ diss. Athens)

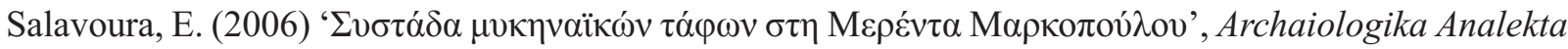
ex Athenon 39, 61-82

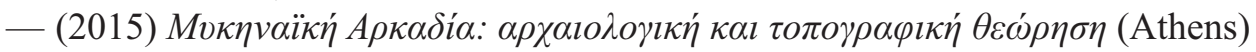

Schallin, A.-L. and Tournavitou, I. (eds) (2015) Mycenaeans up to Date: The Archaeology of the Northeastern Peloponnese: Current Concepts and New Directions (Stockholm)

Schepartz, L.A., Fox, S.C. and Bourbou, C. (eds) (2009) New Directions in the Skeletal Biology of Greece (Hesperia Supplement 43) (Princeton)

Sharma, S. (2017) Placing the Dead: Assessing the Distribution of Tombs in Late Bronze Age Messenia and the Argolid (MA diss. Cambridge)

Sideris, A., Liritzis, I., Liss, B., Howland, M.D. and Levy, T.E. (2017) 'At risk cultural heritage: new excavations and finds from the Mycenaean site of Kastrouli, Phokis, Greece', Mediterranean Archaeology and Archaeometry 17.1, 271-85

Sjöberg, L. (2004) Asine and the Argolid in the Late Helladic III Period: A Socio-economic Study (Oxford)

Smith, R.A.K. (2010) Mochlos IIB: Period IV, the Mycenaean Settlement and Cemetery: The Pottery (Philadelphia)

Smith, R.A.K., Dabney, M.K., Pappi, E., Triantaphyllou, S. and Wright, J.C. (2017) Ayia Sotira: A Mycenaean Chamber Tomb Cemetery in the Nemea Valley, Greece (Philadelphia)

Soles, J.S., Brogan, T.M, Triantaphyllou, S. (2008) Mochlos IIA: Period IV, the Mycenaean Settlement and Cemetery: The sites (Philadelphia)

Soles, J.S. and Davaras, C. (eds) (2011) Mochlos IIC: Period IV, the Mycenaean Settlement and Cemetery: The Human Remains and Other Finds (Philadelphia)

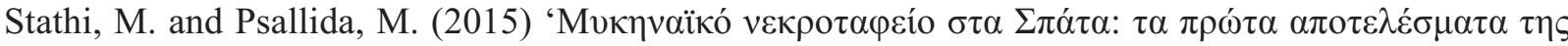
$\mu \varepsilon \lambda \dot{\varepsilon} \tau \eta S^{\prime}$, paper presented at the Athens and Attica in prehistory conference, 27-31 May 2015, ASCSA (Athens) https://www.youtube.com/watch?v=1ScEBxqaeOU

Stavropoulou-Gatsi, M., Jung, R., Mehofer, M. (2012) "Tó

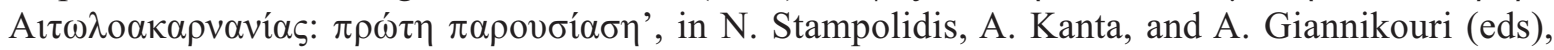
Athanasia: The Earthly, the Celestial and the Underworld in the Mediterranean from the Late Bronze and the Early Iron Age (Heraklion) 249-66

Steinmann, B.F. (2012) Die Waffengraber der ä̈aïschen Bronzezeit: Waffenbeigaben, soziale Selbstdarstellung und Adelsethos in der minoisch-mykenischen Kultur (Wiesbaden)

Stocker, S.R. and Davis, J.L. (2017) 'The combat agate from the grave of the Griffin Warrior at Pylos', Hesperia 86, 583-605

Svenson, O. (2013) Visibility and Tholos Tombs in the Messenian Landscape: A Comparative Case Study of the Pylian Hinterlands and the Soulima Valley (MA thesis, Lund)

Valla, M., Triantaphyllou, S., Halstead, P. and Isaakidou, V. (2013) 'Handling of death at the end of the Late Bronze Age: the case of Faia Petra, 13th c. BC, eastern Macedonia, Greece', in M. Lochner and F. Ruppenstein, F. (eds), Brandbestattungen von der mittleren Donau bis zur Ägäis zwischen 1300 und 750 v. Chr. (Vienna) 231-48

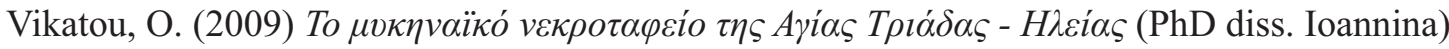

Vlazaki, M. (ed.) (2012) 2000-2010: a https://www.culture.gr/anaskafes/index.html

Voutsaki, S. 1993. Society and Culture in the Mycenaean World: An Analysis of Mortuary Practices in the Argolid, Thessaly and the Dodecanese (PhD diss. Cambridge)

Wiener, M.H. (2015) 'The Mycenaean conquest of Minoan Crete', in C.F. Macdonald, E. Hatzaki and S. Andreou (eds), The Great Islands: Studies of Crete and Cyprus Presented to Gerald Cadogan (Athens) $131-42$

Zavadil, M. (2013) Monumenta: Studien zu mittel- und späthelladischen Gräbern im Messenien (Vienna) 


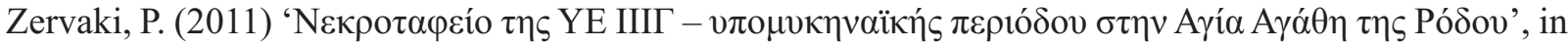
A. Mazarakis Ainian (ed.), The 'Dark Ages'Revisited: Acta of an International Symposium in Memory of William D.E. Coulson (Volos) 725-40

- (2014) 'La nécropole submycénienne de Aghia Agathè', in A. Coulié, A. and M. Filimonos-Tsopotou (eds), Rhodes: une île grecque aux portes de l'Orient, XVe-Ve siècle avant J.-C. (Paris) 190-97 